\title{
ANALISIS KANDUNGAN PROKSIMAT, ANTIOKSIDAN DAN TOKSISITAS EKSTRAK DAUN SAMAMA (Anthocephalus Macrophylus) DENGAN PENAMBAHAN FULI PALA (Myristica fragrant Houtt) SEBAGAI MINUMAN FUNGSIONAL
}

\author{
Khadijah $^{* 1}$, Ahmad Muhsin Jayali ${ }^{1}$, Indah Rodianawati ${ }^{2}$ \\ ${ }_{1}^{1}$ Program Studi Pendidikan Kimia, Universitas Khairun, Ternate \\ ${ }^{2}$ Program Studi Teknologi Hasil Pertanian, Ternate \\ email : ${ }^{* 1}$ talimbangan@gmail.com, 1 jayali.iam@gmail.com, ${ }^{2}$ rodiana79@gmail.com \\ Manuscript recieved:29-09-2019 Revision Accepted: 01-11-2019
}

\begin{abstract}
Samama and Nutmeg Leaf formulations especially in the Fuli section which can be used as additives (flavor) in a food or beverage material is a natural potential that needs to be utilized optimally, so it is necessary to do a more in-depth study of Carbohydrate, Protein and Fat content, as a food ingredient and antioxidant content after mixing Samama extract and Nutmeg mace which is thought to have the ability as an antioxidant so that it can be utilized as a Potential Health Drink for development. In this research, analysis of proximates, antioxidant levels and toxicity of a mixture of dried Samama leaves with Nutmeg mace at various concentrations was $0.1 \% ; 0.25 \%$; $0.5 \%$; $0.75 \%$; and $1 \%$. The results showed that the combination of Samama leaf (Anthocepallus macrophyllus) with Nutmeg mace (Myristica fragrants Houtt) had the ability to reduce free radicals with DPPH method with moderate intensity, where $\mathrm{IC}_{50}$ produced was 117.6 to $126.92 \mu \mathrm{g} / \mathrm{mL}$ (moderate category was $101-150 \mu \mathrm{g} / \mathrm{mL}$ ), with proximate analysis results in accordance with SNI 01-38362013 standards for ash content, crude fiber, protein, carbohydrate and fat levels which are almost the same for each formula followed by toxicity $\left(\mathrm{LC}_{50}\right)<1000 \mu \mathrm{g} / \mathrm{mL}$ in mixtures with mace concentrations of $0.1 \%$ which is $378.27 \mu \mathrm{g} / \mathrm{mL}$ so that they are said to be toxic and not recommended for direct consumption, whereas mace concentrations of more than or equal to $0.25 \%$ are categorized as not toxic because they have an $\mathrm{LC}_{50}>1000 \mu \mathrm{g} / \mathrm{mL}$ so it is safe as a functional drink.
\end{abstract}

Keywords: Samama Leaf, Fuli of Nutmegs, antioxidant, toxicity

\begin{abstract}
Abstrak
Perpaduan daun Samama dan Pala terutama pada bagian fuli yang dapat dijadikan sebagai bahan tambahan (flavor) dalam suatu bahan makanan maupun minuman merupakan potensi alam yang perlu dimanfaatkan secara optimal, sehingga perlu dilakukan kajian lebih mendalam tentang kandungan karbohidrat, protein dan lemak, sebagai suatu bahan pangan dan kandungan antioksidan setelah pencampuran ekstrak Samama dan fuli Pala yang diduga memiliki kemampuan sebagai antioksidan sehingga dapat dimanfaatkan sebagai minuman kesehatan yang potensial untuk dikembangkan. Dalam penelitian ini dilakukan analisis proximat, kadar antioksidan dan toksisitas dari campuran daun kering Samama dengan fuli Pala pada berbagai konsentrasi yaitu $0,1 \% ; 0,25 \% ; 0,5 \% ; 0,75 \%$; dan $1 \%$. Hasil penelitian menunjukkan bahwa perpaduan daun Samama (Anthocepallus macrophyllus) dengan fuli Pala (Myristica fragrants Houtt) memiliki kemampuan mereduksi radikal bebas dengan metode $\mathrm{DPPH}$ dengan intensitas sedang, dimana $\mathrm{IC}_{50}$ yang dihasilkan sebesar 117,6 sampai 126,92 $\mu \mathrm{g} / \mathrm{mL}$ (kategori sedang adalah $101-150 \mu \mathrm{g} / \mathrm{mL}$ ), dengan hasil analisis proximat yang sesuai dengan standar SNI 01-3836-2013 untuk kadar abu, kadar serat kasar, protein, karbohidrat dan lemak yang hampir sama untuk setiap formula dilanjutkan dengan toksisitas $\left(\mathrm{LC}_{50}\right)<1000 \mu \mathrm{g} / \mathrm{mL}$ pada campuran dengan konsentrasi fuli sebesar 0,1\% yaitu 378,27 $\mu \mathrm{g} / \mathrm{mL}$ sehingga dikatakan toksik dan tidak direkomendasikan untuk dikonsumsi secara langsung, sedangkan dengan konsentrasi fuli lebih dari atau sama dengan 0,25\% dikategorikan tidak toksik karena memiliki $\mathrm{LC}_{50}>1000 \mu \mathrm{g} / \mathrm{mL}$ sehingga aman sebagai suatu minuman fungsional.
\end{abstract}

Kata Kunci: Daun Samama, Fuli pala, antioksidan, toksisitas 


\section{PENDAHULUAN}

Keanekaragaman tumbuhan di Indonesia sangat memungkinkan untuk ditemukan beranekaragam jenis senyawa kimia. Beberapa jenis senyawa kimia itu telah banyak ditemukan tetapi berdasarkan sejarah penemuan dan pengembangannya tidak dapat dipungkiri bahwa mungkin akan ditemukan senyawa-senyawa kimia baru yang didapatkan berdasarkan hasil penelitian tanaman-tanaman baru yang akan diteliti.

Berkaitan dengan senyawa kimia hasil metabolit sekunder seperti terpenoid, golongan fenol, alkaloid, flavonoid dan sebagainya banyak sekali terdapat di dalam tumbuhan dan sangat potensial untuk diteliti dan dikembangkan oleh para peneliti di Indonesia dalam rangka pencarian bahan baku obat antioksidan alami (Fitriya., et al., 2010).

Penggunaan sumber daya alam sebagai obat tradisional lebih diminati karena relatif tidak menimbulkan efek samping, berbeda dengan obat-obat sintetik yang seringkali mangakibatkan efek samping yang lebih berbahaya bagi kesehatan. Apalagi setelah krisis ekonomi yang dialami oleh beberapa negara asia termasuk Indonesia menyebabkan melonjaknya harga obatobat sintetik, sehingga daya jangkau masyarakat terhadap obat-obat sintetik semakin rendah. Penggunaan bahan alam sebagai obat tradisional dan sebagai bahan dasar obat merupakan salah satu alternative pengobatan. (Rahmaniar,1996;Nugroho,2006). Hasil survei etnobotani yang dilakukan memperlihatkan bahwa salah satu tumbuhan yang potensial adalah tumbuhan tropika Indonesia yang dikenal dengan nama Jabon Merah. Tumbuhan tersebut banyak ditemukan di daerah Maluku, Maluku Utara dengan nama daerah Samama (Ternate, Halmahera) dan nama latinnya Anthosephalus macrophyllus.

Akhir-akhir ini penggunaan senyawa antioksidan berkembang dengan pesat baik untuk makanan maupun pengobatan. Penggunaan sebagai obat makin berkembang seiring dengan makin bertambahnya pengetahuan tentang aktifitas radikal bebas terhadap beberapa penyakit degeneratif seperti penyakit jantung dan kanker (Endang., et al., 2005.).

Beberapa penelitian pendahuluan menemukan kandungan metabolit sekunder yang dimiliki oleh daun Samama sangat potensial untuk dikembangkan sebagai bahan dasar pembuatan obat, demikian pula dengan kandungan antioksidan pada daun Samama asal Ternate sebesar $80.34 \mu \mathrm{g} / \mathrm{mL}$ pada daun muda dan $43,49 \mu \mathrm{g} / \mathrm{mL}$ pada daun tua (Khadijah., et al.,2017), dimana jika kandungan antioksidan $\left(\mathrm{IC}_{50}\right)<50 \mu \mathrm{g} / \mathrm{mL}$, intensitasnya sangat kuat dan antioksidan $\left(\mathrm{IC}_{50}\right)$ $=50-100 \mu \mathrm{g} / \mathrm{mL}$, intensitasnya kuat (Armala, 2009).

Penelitian ini dilakukan untuk mengetahui kandungan kadar air, abu, protein, karbohidrat, lemak dan serat kasarnya (analisis proximate), kandungan antioksidan serta toksisitas dari ekstrak daun Samama yang telah ditambahkan pala sebagai perisai alami sehingga dapat dimanfaatkan sebagai suatu bahan pangan fungsional.

\section{METODE PENELITIAN}

Metode penelitian ini mengacu pada metode penelitian yang lazim digunakan dalam mengisolasi senyawa organik bahan alam yang meliputi pemilihan spesies, penentuan lokasi pengambilan sampel, persiapan dan pengambilan sampel tumbuhan, pengolahan sampel yang meliputi ekstraksi, uji antioksidan, uji toksisitas. 


\section{B.1.. Waktu dan Tempat Pengambilan Sampel}

Penelitian ini dilakukan pada bulan Mei-November 2018 di Laboratotium Dasar dan Laboratorium Kimia, FKIP Unkhair. Sampel daun Anthocephalus macrophyllus diambil dari kampus II Unkhair di kelurahan Gambesi, Kecamatan Kota Ternate selatan, Kota Ternate, Maluku Utara.

\section{B.2.. Alat Penelitian}

Oven listrik, timbangan analitik, cawan aluminium, desikator, tang penjepit, cawan porselen 30 $\mathrm{mL}$, pembakar bunsen atau hot plate, tanur listrik, labu Kjeldahl $300 \mathrm{~mL}$, Satu set alat destilasi, erlenmeyer $250 \mathrm{cc}$, buret $50 \mathrm{cc}$ skala $0.1 \mathrm{~mL}$, aatu set alat sokhlet, kertas saring bebas lemak, corong, erlenmeyer, petridish, penangas air, pipet ukur $10 \mathrm{~mL}$, alat penghitung koloni (colony counter), tabung reaksi, alat penghomogen (vortex), rak tabung reaksi, tissue, LAF, inkubator, autoklaf.

\section{B.3. Bahan Penelitian}

$\mathrm{H}_{2} \mathrm{SO}_{4}$ teknis dan p.a., $\mathrm{HCl} 0.1 \mathrm{~N}, \mathrm{NaOH} 32 \%$, tablet Kjedahl, asam borax 3\%, indikator Methyl Red, indikator pp, Buffered Peptone Water (BPW), PCA (Plate Count Agar), alkohol 70 \%, alkohol $80 \%$, alkohol 96\%, larutan Luff Schrool, $\mathrm{HCl} 3 \%$, $\mathrm{KI} 20 \%, \mathrm{H}_{2} \mathrm{SO}_{4} 25 \%$, $\mathrm{CaCO}_{3}$, larutan Nathiosulfat $0.1 \mathrm{~N}, \mathrm{~Pb}$ asetat, asam oksalat, Pereaksi anthrone $0.1 \%$, Larutan glukosa standar 0.2 $\mathrm{mg} / \mathrm{ml}, \mathrm{HCl} 25 \%, \mathrm{H}_{2} \mathrm{SO}_{4} 1.25 \%, \mathrm{NaOH} 3.25 \%, \mathrm{NaOH} 10 \%, \mathrm{HCl}$ pekat, $\mathrm{NH}_{4} \mathrm{OH} 12 \%$, dan Petroleum eter.

\section{B.4. Prosedur Penelitian}

\section{Ekstraksi}

Sampel Anthocephalus macrophyllus dibagi atas dua bagian, yatu sampel daun muda dan tua yang masih segar (fresh) dan sampel daun muda dan tua yang sudah dikeringkan. Kemudian sampel ditimbang lalu dihaluskan dengan blender kemudian ditambahkan dengan bubuk pala (fuli) $(\% \mathrm{~b} / \mathrm{b})$, selanjutnya dilakukan pengujian analisis proximat, antioksidan dan toksisitas dengan melarutkan dalam alkohol dan air.

\section{Analisa Proksimat}

Penentuan Kadar Air, adapun cara kerjanya adalah cawan porselen yang telah dicuci bersih, dikeringkan di dalam oven selama 1 jam dengan temperatur $105{ }^{\circ} \mathrm{C}$. kemudian didinginkan di dalam eksikator sekitar 10-20 menit dan ditimbang (C). Sampel dihitung sebanyak 0,5-1 gram (D) dan dimasukkan ke dalam cawan porselen. Kemudian cawan dan sampel tersebut dikeringkan dalam open $105^{\circ} \mathrm{C}$ selama 112-16 jam. Cawan dan sampel (E) dikeluarkan dari oven dan didinginkan dalam eksikator selama 10-20 menit sampai diperoleh berat tetap.

Penentuan Kadar Abu, adapun cara kerjanya antara lain : cawan porselen yang telah dicuci bersih, dikeringkan di dalam oven sekitar 1 jam pada temperatur $105^{\circ} \mathrm{C}$. kemudian didinginkan dalam eksikator sekitar 10-20 menit dan ditimbang dengan teliti (F). Sampel ditimbang dengan teliti sebanyak 3 gram untuk sampel hijauan atau 5 gram untuk kosentrat (G) dan dimasukkan ke dalam cawan porselen. Pijarkan sampel yang terdapat dalam cawan porselen hingga 
berasap. Bakar cawan porselen berisi sampel dan tanur bersuhu $600^{\circ} \mathrm{C}$. biarkan sampel terbakar selama 3-4 jam atau sampai warna sampel berubah menjadi putih semua. Setelah sampel bewarna putih semua, kemudian dinginkan dalam tanur pada suhu $120^{\circ} \mathrm{C}$ sebelum dipindahkan ke dalam eksikator. Setelah dingin timbang dengan teliti $(\mathrm{H})$.

Penentuan Protein Kasar, adapun cara kerjanya antara lain: timbang sampel dengan teliti sejumlah 0,3 gram (I) dan masukkan kedalam tabung destruksi. Tambahkan kira-kira 0,2 gram katalis campuran dan $5 \mathrm{ml} \mathrm{H}_{2} \mathrm{SO}_{4}$ pekat. Panaskan campuran tersebut dalam lemari asam. Perhatikan proses destruksi selama pemanasan agar tidak meluap. Destruksi dihentikan bila larutan sudah menjadi hijau terang atau jernih, lalu dinginkan dalam lemari asam. Larutan dimasukkan ke dalam labu destilasi dan diencerkan dengan $60 \mathrm{ml}$ aquades. Masukkan beberapa buah batu didih. Tambahkan pelan-pelan melalui dinding labu $20 \mathrm{ml} \mathrm{NaOH} 40 \%$ dan segera hubungkan dengan destilator. Suling $\left(\mathrm{NH}_{3}\right.$ dan air) ditangkap oleh labu erlenmeyer yang berisi $25 \mathrm{ml} \mathrm{H}_{2} \mathrm{SO}_{4} 0,3 \mathrm{~N}$ dan 2 tetes indikator campuran (methyl red 0,1\% dan bromcresol green $0,2 \%$ dalam alkohol). Penyulingan dilakukan hingga nitrogen dari cairan tersebut tertangkap oleh $\mathrm{H}_{2} \mathrm{SO}_{4}$ yang ada di dalam erlenmeyer (2/3 dari cairan yang ada pada labu destilasi menguap atau terjadi letupan-letupan kecil atau erlenmeyer mencapai volume $75 \mathrm{ml}$ ). Labu erlenmeyer berisi sulingan diambil dan dititer kembali dengan $\mathrm{NaOH} \mathrm{0,3N} \mathrm{(J).} \mathrm{Perubahan}$ biru ke hijau menandakan titik akhir titrasi. Bandingkan dengan titer blanko (K).

Penentuan Lemak Kasar antara lain: timbang sampel dengan teliti sebanyak 1 gram 9 L) dan bungkus dengan kertas saring bebas lemak. Keringkan dalam oven $105^{\circ} \mathrm{C}$ selama 5 jam, dinginkan dalam eksikator dan timbang (M). Sampel dimasukkan kedalam tabung ekstraksi soxhlet. Alat soxhlet diisi dengan pelarut lewat kondensor dengan corong. Alat pendingin dialirkan dan panas dihidupkan. Ekstraksi berlangsung selama 16 jam sempai pelarut pada alat soxhlet terlihat jernih. Sampel dikeluarkan dari alat soxhlet dan keringkan ke dalam oven $105^{\circ} \mathrm{C}$ selama 5 jam, kemudian dinginkan dalam eksikator dan timbang $(\mathrm{N})$.

Penentuan Serat Kasar antara lain: keringkan kertas saring whatman No. 41 di dalam oven 105C selama 1 jam dan timbang $(\mathrm{O})$. timbang dengan teliti 1 gram (P) sampel masukkan kedalam gelas piala. Tambahkan $50 \mathrm{ml} \mathrm{H}_{2} \mathrm{SO}_{4} 0,3 \mathrm{~N}$ dan didihkan selama 30 menit. Cairan disaring melalui kertas saring yang telah diketahui beratnya didalam corong Buchner yang telah dihubungkan dengan pompa vokum. Kertas saring bersama residu dicuci berturut-turut dengan $50 \mathrm{ml} \mathrm{H}_{2} \mathrm{O}$ panas, $50 \mathrm{ml} \mathrm{H}_{2} \mathrm{SO}_{4} 0,3 \mathrm{~N}, 50 \mathrm{ml} \mathrm{H}_{2} \mathrm{O}$ panas dan aseton. Kertas saring berisi residu dimasukkan kedalam cawan porselen bersih dan kering dengan menggunakan oven. Cawan berisi sampel yang dikeringkan ke dalam oven $105^{\circ} \mathrm{C}$ sampai didapat berat yang konstan, didinginkan dalam eksikator dan ditimbang (Q). Pijarkan sampel dalam cawan hingga tak berasap. Kemudian cawan bersama isinya dimasukkan ke dalam tanur $600^{\circ} \mathrm{C}$ selama 3-4 jam. Setelah isi cawan berubah menjadi abu yang bewarna putih, diangkat, didinginkan dan ditimbag (R).

Kadar Karbohidrat dengan cara mengurangkan kandungan zat makanan dalam bahan pakan (\% abu, protein kasar, lemak kasar, dan serat kasar) dari \% BK bahan.

\section{Uji Aktivitas Antioksidan}

Aktivitas antioksidan dianalisa dengan terlebih dahulu membuat larutan DPPH (1,1-diphenyl2-phikril-hidrazil) yaitu melarutkan Kristal DPPH kedalam methanol pada konsentrasi 0,01 M. Kemudian, mengambil $1 \mathrm{ml}$ DPPH 0,01 M dan menambahkan metanol hingga volumenya 5 
ml,lalu mengukur absorbansinya pada panjang gelombang $517 \mathrm{~nm}$ sebagai absorbansi kontrol. Proses selanjutnya yaitu pengukuran absorbansi sampel dari ekstraksi dengan pelarut nheksana. Langkah pengukuran absorbansi sampel dengan mengambil $200 \mathrm{mg}$ sampel dan melarutkannya dalam $5 \mathrm{ml}$ metanol sambil memvortek selama 1 jam. Kemudian, mengambil 1 $\mathrm{ml}$ campuran tersebut dan menambahkan $1 \mathrm{ml}$ DPPH 0,01 M serta metanol hingga volumenya $5 \mathrm{ml}$. Kemudian sampel diukur absorbansinya pada panjang gelombang $517 \mathrm{~nm}$. Mengulangi analisa absorbansi sampel dengan sampel dari hasil ekstraksi dengan pelarut chloroform dan etil asetat. Data absorbansi sampel yang diperoleh digunakan untuk penentuan Inhibition Concentration (IC) (\%). Inhibition Concentration (IC) (\%) yaitu konsentrasi suatu zat antioksidan yang menyebabkan 50\% DPPH kehilangan karakter radikal.

\section{Uji Toksisitas dengan Menggunakan Metode Brine Shrimp Lethality Test (BSLT)}

\section{Penyiapan sampel}

Sampel ditimbang sebanyak $100 \mathrm{mg}$, ditambahkan kloroform sampai dengan volume $10 \mathrm{~mL}$ (konsentrasi larutan induk $=10 \mathrm{mg} / \mathrm{ml}$ ). Dari larutan induk dipipet ke dalam vial masingmasing 0,5 ml, 0,05 ml, 0,005 ml sehingga diperoleh konsentrasi $10 \mu \mathrm{g} / \mathrm{ml}, 100 \mu \mathrm{g} / \mathrm{ml}, 1000$ $\mu \mathrm{g} / \mathrm{ml}$, kemudian pelarutnya diuapkan lalu ditambahkan $3 \mathrm{ml}$ air laut.

\section{Penyiapan larva Artemia salina Leach}

Telur Artemia salina Leach dimasukkan ke wadah berisi air laut, diaerasi di bawah sinar lampu selama 24 jam. Telur akan menetas setelah 24 jam dan menjadi larva. Aerasi diteruskan selama 24 jam. Larva yang berumur 2 (dua) hari digunakan sebagai hewan uji.

\section{Pelaksanaan pengujian}

Ke dalam masing-masing vial yang berisi sampel uji serta kontrol dimasukkan 10-15 ekor larva udang. Volume vial dicukupkan hingga $5 \mathrm{ml}$ dengan air laut. Setelah 24 jam, dilakukan pengamatan jumlah larva udang yang mati. Tiap sampel uji dan kontrol dilakukan replikasi sebanyak 3 kali. (Kontrol = kloroform 0,5 ml diuapkan, dikerjakan seperti penetapan sampel uji).

\section{Pengumpulan dan Analisa Data}

Data pengamatan jumlah larva yang mati dari masing-masing perlakuan dikumpulkan kemudian dihitung persentase kematian yang selanjutnya dianalisis probit untuk memperoleh $\mathrm{LC}_{50}(\mu \mathrm{g} / \mathrm{mL})$.

\section{HASIL DAN PEMBAHASAN}

Pada penelitian ini dilakukan pemeriksaan berupa analisis proximat berupa kadar air, abu, protein, lemak, karbohidrat dan serta kasar berdasarkan metode AOAC pada campuran daun Samama dan fuli pala dengan berbagai konsentrasi (formulasi) $0,1 \% ; 0,25 \% ; 0,5 \% ; 0,75 \%$; dan 1\% dalam 2 gram daun Samama yang telah dikeringkan tanpa terkena matahari langsung, untuk menghindari rusaknya senyawa kimia bila terkena matahari langsung seperti senyawasenyawa flavonoid dan volatile. Selanjutnya dilakukan pengukuran aktivitas antioksidan dengan metode DPPH pada formula yang telah ditentukan sebelumnya. Kemudian untuk 
mengetahui toksisitas dari suatu bahan pangan fungsional dilakukan uji sitotoksik dengan menggunakan pengujian terhadap kematian larva udang Artemia salina leach atau Brine Shrimp Lathality Test (uji BSLT) seperti disajikan dalam tabel berikut ini:

Tabel 1, Hasil uji Proximat

\begin{tabular}{ccccccc}
\hline Formulasi & Air $(\%)$ & $\begin{array}{c}\text { Abu } \\
(\%)\end{array}$ & $\begin{array}{c}\text { Protein } \\
(\%)\end{array}$ & $\begin{array}{c}\text { Lemak } \\
(\%)\end{array}$ & $\begin{array}{c}\text { Serat } \\
\text { Kasar }(\%)\end{array}$ & $\begin{array}{c}\text { Karbohidrat } \\
(\%)\end{array}$ \\
\hline A & 10,71 & 7,12 & 10,27 & 2,96 & 16,05 & 52,89 \\
B & 10,64 & 7,38 & 10,44 & 3,11 & 16,58 & 51,85 \\
C & 10,66 & 7,28 & 10,07 & 3,05 & 15,69 & 53,25 \\
D & 10,82 & 7,43 & 10,73 & 2,90 & 15,78 & 52,34 \\
E & 10,81 & 7,31 & 10,12 & 2,43 & 16,70 & 52,62 \\
SNI 01-3836-2013 & $<10 \%$ & $<8 \%$ & & & $<16 \%$ & \\
\hline
\end{tabular}

Keterangan:

$\mathrm{A}=$ fuli $0,1 \% \mathrm{~b} / \mathrm{b} ; \mathrm{B}=$ fuli $0,25 \% \mathrm{~b} / \mathrm{b} ; \mathrm{C}=$ fuli $0,5 \% \mathrm{~b} / \mathrm{b} ; \mathrm{D}=$ fuli $0,75 \% \mathrm{~b} / \mathrm{b}$ dan $\mathrm{E}=$ fuli $1 \% \mathrm{~b} / \mathrm{b}$

Air merupakan komponen penting dalam bahan pangan karena air dapat mempengaruhi penampakan, tekstur dan citarasa makanan. Persyaratan kadar air dalam suatu ramuan merupakan parameter penting untuk menilai keadaan ramuan tersebut. Berdasarkan data pada Tabel 1, formula B memiliki kadar air paling kecil yaitu 10,64\%, dan terbesar pada Formula D yaitu 10,82\%. Kadar air yang dimiliki oleh kelima formulasi Samama dan fuli tersebut belum memenuhi standar untuk simplisia kering, yaitu lebih dari $10 \%$ namun hal ini dapat disiasati dengan waktu pengeringan yang lebih lama untuk mengurangi kadar air dari suatu sampel atau simplisia. Keberadaan air dalam bahan pangan juga ikut menentukan terjadinya kerusakan dalam bahan pangan tersebut, karena air dapat dimanfaatkan oleh mikroorganisme untuk pertumbuhannya (Fardiaz et al., 1992).

Kadar abu suatu bahan menunjukkan keberadaan kandungan mineral atau bahan-bahan anorganik. Berdasarkan analisis kadar abu pada Tabel 1, Formula D memiliki lebih banyak bahan anorganik dibandingkan formula lainnya. Hal ini terlihat dari nilai kadar abu formula D yang lebih besar daripada kadar abu lainnya. Menurut Gaman dan Sherrington (1992), unsur mineral adalah unsur yang diperlukan tubuh dalam jumlah yang relatif kecil, tetapi keberadaannya tetap diperlukan sebagai zat pembangun dan pengatur.

Lemak merupakan salah satu komponen penting pada bahan pangan. Pada sayuran dan buahbuahan komponen ini umumnya dijumpai dalam 26 jumlah yang kecil, yaitu tidak lebih dari $0,5 \%$ basis basah (Potter dan Hotchkiss, 1995). Kelima formula yang digunakan untuk pembuatan teh herbal ini memiliki kadar lemak yang rendah. Kandungan lemak yang rendah dalam buah-buahan dan sayuran mempunyai peranan penting dalam mempertahankan tekstur, rasa, bau, zat warna dan lain-lain (Pantastico, 1986).

Kelompok nutrien lain yang penting adalah protein. Protein merupakan penyusun utama selsel tubuh. Membran sekeliling sel terbuat dari protein. Protein juga didapatkan didalam sel. Protein penting untuk pembentukan enzim, antibodi, dan beberapa hormon. Substansi ini diproduksi dalam sel dan dalam beberapa hal dilepaskan ke aliran darah (antibodi dan hormon) atau ke dalam usus (enzim pencernaan) (Gaman dan Sherrington, 1992). Menurut Suhardjo dan Clara (1987), bahan-bahan protein dapat diperoleh tanaman dari tanah dan udara sekitarnya dan nitrogen yang diperoleh dari tanah berada dalam bentuk senyawa nitrat dan nitrit. 
Serat merupakan salah satu zat yang dibutuhkan oleh tubuh karena serat dapat membantu memperlancar pencernaan pada tubuh manusia. Fungsi utama serat adalah (1) memperlambat kecepatan pencernaan pati sehingga aliran energi ke tubuh menjadi berkurang, (2) memperlambat pengosongan lambung sehingga memberi perasaan kenyang yang lebih lama, (3) memperlambat penyerapan glukosa dalam usus sehingga membantu mengatur kebutuhan insulin (4) meningkatkan kebutuhan saluran pencernaan dengan cara meningkatkan motilitas atau pergerakan usus besar, (5) mengurangi resiko penyakit jantung, (6) mengikat asam empedu dalam usus, (7) mengikat lemak dan kolesterol dalam usus halus yang kemudian dikeluarkan melalui feses (Stark dan Madar, 1994). Berdasarkan hasil analisis kadar serat kasar pada penelitian ini, daun ceremai memiliki kandungan serat yang cukup tinggi. Kandungan serat yang tinggi dalam bahan makanan berguna untuk memperlancar pencernaan dalam tubuh. Serat kasar menurut Muchtadi (1989) merupakan residu dari makanan yang tidak dapat dihidrolisis dengan bahan kimia.

Berdasarkan data penelitian yang dilakukan untuk semua jenis formulasi telah memenuhi standar SNI 01-3836-2013 untuk teh herbal kering dalam kemasan.

Tabel 2. Aktivitas Antioksidan dan Toksisitas

\begin{tabular}{ccc}
\hline Formulasi & $\begin{array}{c}\text { Antioksidan } \\
\text { (IC50) }\end{array}$ & $\begin{array}{c}\text { Toksisitas } \\
\text { (LC50) }\end{array}$ \\
\hline A & 117,60 & 378.27 \\
B & 121,29 & 1122 \\
C & 126,92 & 317029.74 \\
D & 119,31 & 9366.99 \\
E & 122.90 & $2,58 \times 10^{9}$ \\
\hline
\end{tabular}

Keterangan:

$A=$ fuli $0,1 \% b / b ; B=$ fuli $0,25 \% b / b ; C=$ fuli $0,5 \% b / b ; D=$ fuli $0,75 \% b / b$ dan $E=$ fuli $1 \% b / b$

Berdasarkan penelitian yang telah dilakukan oleh Khadijah,dkk (2017) telah diketahui kadar antioksidan dari daun Samama (Anthocepallus macrophyllus) sebesar $80.34 \mu \mathrm{g} / \mathrm{mL}$ pada daun muda, dan $43.49 \mu \mathrm{g} / \mathrm{mL}$ pada daun tua Samama. Pada penambahan fuli pala terlihat penurunan aktivitas antioksidan dan niai toksisitas dari simplisia daun Samama. Hal ini juga dipengaruhi oleh jenis daun Samama yang dimanfaatkan yaitu sebagian besar adalah daun muda dengan menambahkan pula sedikit daun tua. Terlihat pada Tabel 2, aktivitas antioksidan dengan formulasi yang berbeda menunjukkan aktivitas penangkapan radikal bebas hampir sama untuk semua formulasi yang dilakukan dimana intensitas kekuatan antioksidan berada pada level sedang (101-150 $\mathrm{\mu g} / \mathrm{ml}$ ). Menurut Molyneux (2004), ekstrak dinyatakan sebagai antioksidan bila nilai $\mathrm{IC}_{50}$ kurang dari $200 \mu \mathrm{g} / \mathrm{ml}$. Daya hambat terhadap radikal bebas DPPH diukur secara spektrofotometri UV-VIS berdasarkan perubahan warna yang terjadi.

Pada pengukuran toksisitas dengan menggunakan uji BSLT menunjukkan bahwa semakin besar fuli yang ditambahkan, maka toksisitasnya semakin menurun, sehingga aman untuk dikonsumsi sebagai suatu bahan pangan fungsional (minuman fungsional).

\section{KESIMPULAN}

Dalam penelitian ini dilakukan analisis proximat, kadar antioksidan dan toksisitas dari campuran daun kering Samama dengan fuli pala pada berbagai konsentrasi yaitu 0,1\%; 0,25\%; $0,5 \% ; 0,75 \%$; dan $1 \%$. Hasil penelitian menunjukkan bahwa perpaduan daun Samama (Anthocepallus macrophyllus) dengan fuli Pala (Myristica fragrants Houtt) memiliki kemampuan 
mereduksi radikal bebas dengan metode $\mathrm{DPPH}$ dengan intensitas sedang, dimana $\mathrm{IC}_{50}$ yang dihasilkan sebesar 117,6 sampai 126,92 $\mu \mathrm{g} / \mathrm{mL}$ (kategori sedang adalah 101-150 $\mu \mathrm{g} / \mathrm{mL}$ ), dengan hasil analisis proximat yang sesuai dengan standar SNI 01-3836-2013 untuk kadar abu, kadar serat kasar, protein, karbohidrat dan lemak yang hampir sama untuk setiap formula dilanjutkan dengan toksisitas $\left(\mathrm{LC}_{50}\right)<1000 \mu \mathrm{g} / \mathrm{mL}$ pada campuran dengan konsentrasi fuli sebesar $0,1 \%$ yaitu $378,27 \mu \mathrm{g} / \mathrm{mL}$, sedangkan dengan penambahan fuli lebih dari atau sama dengan $0,25 \%$ dikategorikan tidak toksik karena memiliki $\mathrm{LC}_{50}>1000 \mu \mathrm{g} / \mathrm{mL}$ sehingga aman sebagai suatu minuman fungsional.

\section{UCAPAN TERIMAKASIH}

Terima kasih kepada LPPM Universitas Kharun yang telah membiayai penelitian ini melalui Hibah penelitian tingkat Fakultas dengan nomor 674/UN44/KU.08/2019.

\section{DAFTAR PUSTAKA}

Achmad, S.A. 2007. Keanekaragaman Hayati dalam Pembelajaran Ilmu Kimia. Makalah disajikan dalam Seminar Nasional Kimia, Jurusan Kimia Universitas Negeri Makassar, Makassar, 5 September.

Armala, M. M., 2009, Daya Antioksidan Fraksi Air Ekstrak Herba Kenikir (Cosmos caudatuc HBK) dan Profil KLT, Skripsi, Fakultas Farmasi UII, Yogyakarta

Atun, S. 2005. Pengembangan Potensi Bahan Alam sebagai Sumber Penemuan Obat Baru. Makalah disajikan dalam Seminar Nasional Kimia, Universitas Negeri Yogyakarta, Yogyakarta, 24 September.

Bhakuni, R.S., Shukla, Y.N. and Thakur, R.S. 1991. Melochicorine, A Pseudooxindole Alkaloid from Melochia corchorifolia. Phytochemistry, 30(9): 3159-3160.

Chakrabarti, R., Vikramadithyan, R.K., Mullangi, R., Sharma, V.M., Jagadheshan, H., Rao, Y.N., Sairam, P. and Rajagopalan, R. 2002. Antidiabetic and Hypolipidemic Activity of Helicteres isora in Animal Models. Journal of Ethnopharmacology, 81(3): 343-349.

Delporte, C., Backhouse, N., Erazo, S., Negrete, R., Vidal, P., Silva, X., Lopez-Perez, J.L., Feliciano, A.S. and Munoz, O. 2005. Analgesic-Antiinflammatory Properties of Proustia pyrifolia. Journal of Ethnopharmacology, 99, 119-124.

Dini, I. 2005. Penelusuran Metabolit Sekunder Ekstrak Kulit Batang Tumbuhan Paliasa (Kleinhovia hospita Linn.) dan Bioaktivitasnya terhadap Artemia salina Leach. Tesis tidak diterbitkan. Makassar: Program Pascasarjana Universitas Hasanuddin.

Ersam, T. 2004. Keunggulan Biodiversitas Hutan Tropika Indonesia dalam Merekayasa Model Molekul Alami. Makalah disajikan dalam Seminar Nasional Kimia VI, Jurusan Kimia FMIPA ITS, (Online),(http://www.its.ac.id/personal/files/pub/764-beckers-chem-

Kimia\%20ITS\%20TE\%2004.pdf, diakses 29 oktober 2007).

Fitriya., Anwar, L. dan Novitasari E.,2010., Isolasi Senyawa Fenolat dari Fraksi Etil Asetat Kulit Batang Tumbuhan Gandaria. Jurnal Penelitian Sains, 13(1) C : 13103 hal 10-14 
Gaman, P. M. and K. B. Sherrington. 1992., The Science of Food, An Introduction To Food Science, Nutrition and Microbiology 2nd Edition., diterjemahkan oleh Murdijati Gardjito, Sri Naruki, Agnes Murdiati, Sardjono). UGM Press.Yogyakarta.

Garuda, A., 2006, "Makanan dan Obat dari Laut: Potensi Rumput Laut", The Inflight Magazine of Lion Air 10: 32-35.

Harborne. 1987. Metode Fitokimia: Penuntun Cara Modern Menganalisis Tumbuhan, diterjemahkan oleh Kosasih Padmawinata \& Iwang Soediro. Penerbit ITB, Bandung.

Heyne, K. 1987. Tumbuhan Berguna Indonesia, Jilid 3. Departemen Kehutanan, Jakarta. Hoelzel, S.C.S.M., Vieira, E.R., Giacomelli, S.R., Dalcol, I.I., Zanatta, N.and Morel, A.F. 2005. An Unusual Quinolinone Alkaloid from Waltheria douradinha. Phytochemistry 66(10): 1163 1167.

Hulawane. J. E., Hidayah. H. N., Kinho. J., 2011. Prospek Pengembangan Jabon Merah Anthocephalus macrophyllus (Roxb.) Havill, Solusi Kebutuhan Kayu Masa Depan. Balai enelitian Kehutanan, Manado, Sulawesi Utara.

Khadijah., Jayali, A Muhsin.,Umar, Sudir., Sasmita, Iin.,2017., Penentuan Total Fenolik Dan Aktivitas Antioksidan Ekstrak Etanolik Daun Samama (Anthocephalus Macrophylus) Asal Ternate, Maluku Utara. Jurnal Kimia Mulawarman,15(1),11 -18

Meyer, N., Ferriginii, N.R., Putnam, J.E, Jacobsen,n D.E., Nichols, D.E., McLaughin, J.L., 1982, Brine Shrimp: A Convinient General Bioassay for Active Plant Constituens, Planta Med, 45, 31.

Morel, A.F., Flach, A., Zanatta, N., Ethur, E.M., Mostardeiro, M.A. and Gehrke, I.T.S. 1999. A New Cyclopeptide Alkaloid from The Bark of Waltheria douradinha. Tetrahedron Letters 40(52): 9205 - 9209.

Muchtadi, D. 1989. Evaluasi Nilai Gizi Pangan. Pusat Antar Universitas Pangan dan Gizi. IPB. Bogor

Mudjirahmini, D. dan Ersam, T. 2006. 4-Fenilkumarin pada Fraksi Polar Ekstrak Etil Asetat dari Batang Garcinia balica Miq. Makalah disajikan dalam Seminar Nasional Kimia VIII, Jurusan Kimia FMIPA ITS, Surabaya, 8 Agustus.

Molyneux, p. 2004. The Use Of Teh Stable Free Radical DPPH For Estimasing Antioxidant Activity. J. Science Tecnology. 26(3) : 211-219.

Nugroho, A.E. 2006. Hewan Percobaan Diabetel Mellitus : Patologi dan Mekanisme Aksi Diabetogenik. Biodiversitas 7 (4) : 378-382

Rachmaniar. 1994. Penelitian Produk Alam Laut, Skreening Substansi Bioaktif. Laporan Penelitian Proyek Sumber daya laut. Puslitbang Oseanologi LIPI. Jakarta

Suhardjo dan Clara M. Kusharto. 1988. Prinsip-Prinsip Ilmu Gizi., Penerbit IPB. Bogor 
TECHNO: Vol. 08 ( 02) Oktober 2019

Stark, A. and Z. Madar. 1994. Dietary fiber. In Functional Food. Goldberg, L (Ed.). 1994. . Chapman and Hall. 